\title{
Emergence of Amoxicillin Resistance and Identification of Novel Mutations of the pbp1A Gene in Helicobacter pylori in Vietnam
}

\section{Trung Thien Tran}

Department of Surgery, University of Medicine and Pharmacy at Ho Chi Minh City

Anh Tuan Nguyen ( $\square$ anh.nt@umc.edu.vn )

Molecular Biomedical Center, University Medical Center, Ho Chi Minh City

Duc Trong Quach

Department of Internal Medicine, University of Medicine and Pharmacy at Ho Chi Minh City

Dao Thi-Hong Pham

Department of Genetics, University of Science, Vietnam National University Ho Chi Minh

\section{Nga Minh Cao}

Department of Microbiology-Parasitology, University of Medicine and Pharmacy at Ho Chi Minh City

\section{Uyen Thi-Hong Nguyen}

Department of Genetics, University of Science, Vietnam National University Ho Chi Minh

\section{An Nguyen-Thanh Dang}

Department of Genetics, University of Science, Vietnam National University Ho Chi Minh

\section{Minh Anh Tran}

Department of Surgery, University of Medicine and Pharmacy at Ho Chi Minh City

Loc Huu Quach

University Medical Center - Campus 2, Ho Chi Minh City

\section{Khiem Thien Tran}

University Medical Center - Campus 2, Ho Chi Minh City

Nhan Quang Le

Department of Endoscopy, University Medical Center, Ho Chi Minh City

\section{Viet Van Ung}

Department of Endoscopy, University Medical Center, Ho Chi Minh City

\section{Minh Ngoc-Quoc Vo}

Department of Endoscopy, University Medical Center, Ho Chi Minh City

\section{Danh Thanh Nguyen}

Molecular Biomedical Center, University Medical Center, Ho Chi Minh City

\section{Kha Dong Kha}

Molecular Biomedical Center, University Medical Center, Ho Chi Minh City

\section{Trung Le Tran}


Department of Oral Biology, Yonsei University College of Density, Seoul

\section{Vy Thuy Nguyen}

Department of Genetics, University of Science, Vietnam National University Ho Chi Minh

\section{Research Article}

Keywords: Amoxicillin resistance, Helicobacter pylori, mutation, pbp1A gene, Vietnam

Posted Date: December 2nd, 2021

DOI: https://doi.org/10.21203/rs.3.rs-1099024/v1

License: (c) (i) This work is licensed under a Creative Commons Attribution 4.0 International License. Read Full License

Version of Record: A version of this preprint was published at BMC Microbiology on February 3rd, 2022. See the published version at https://doi.org/10.1186/s12866-022-02463-8. 


\section{Abstract \\ Background}

Amoxicillin resistant Helicobacter pylori $(H$. pylori) strains seem to have increased over time in Vietnam. This threatens the effectiveness of $H$. pylori eradication therapies with this antibiotic. This study aimed to investigate the prevalence of primary resistance of $H$. pylori to amoxicillin and to assess its association with $p b p 1 A$ point mutations in Vietnamese patients.

\section{Materials and Methods}

Naive patients who presented with dyspepsia undergoing upper gastrointestinal endoscopy were recruited. Rapid urease tests and PCR assays were used to diagnose H. pylori infection. Amoxicillin susceptibility was examined by E-tests. Molecular detection of the mutant $p b p 1 A$ gene conferring amoxicillin resistance was carried out by real-time PCR followed by direct sequencing of the PCR products. Phylogenetic analyses were performed using the Tamura-Nei genetic distance model and the neighbour-joining tree building method.

\section{Results}

There were 308 patients $(46.1 \%$ men and $53.9 \%$ women, $\mathrm{p}=0.190)$ with $\mathrm{H}$. pylori infection. The mean age of the patients was $40.5 \pm 11.4$ years, ranging from 18 to 74 years old. The E-test was used to determine the susceptibility to amoxicillin (minimum inhibitory concentration (MIC) $\leq 0.125 \mu \mathrm{g} / \mathrm{ml}$ ) in 101 isolates, among which the rate of primarily resistant strains to amoxicillin was $25.7 \%$. Then, 270 sequences of pbp $1 A$ gene fragments were analysed. There were 77 amino acid substitution positions investigated, spanning amino acids $310-596$, with the proportion varying from $0.4-100 \%$. Seven amino acid changes were significantly different between amoxicillin-sensitive $\left(\mathrm{Amox}^{\mathrm{S}}\right)$ and amoxicillin-resistant $\left(\mathrm{Amox}^{\mathrm{R}}\right)$ samples, including Phe 366 to Leu $(p<0.001), \operatorname{Ser}_{414}$ to $\operatorname{Arg}(p<0.001), \mathrm{Glu} / \mathrm{Asn}_{464-465}(p=0.009), \mathrm{Val}_{469}$ to Met $(p=0.021)$, Phe $_{473}$ to Val $(p<0.001), \operatorname{Asp}_{479}$ to Glu $(p=0.044)$, and Ser/Ala/Gly ${ }_{595-596}(p=$ 0.001). Phylogenetic analyses suggested that other molecular mechanisms might contribute to amoxicillin resistance in $H$. pylori in addition to the alterations in PBP1A.

\section{Conclusions}

We reported the emergence of amoxicillin-resistant Helicobacter pylori strains in Vietnam and new mutations statistically associated with this antimicrobial resistance. Additional studies are necessary to identify the mechanisms contributing to this resistance in Vietnam.

\section{Introduction}


Helicobacter pylori (H. pylori) is a Gram-negative microaerophilic pathogenic bacterium that colonises the human gastric mucosa. It has been categorised as a Group I carcinogen for gastric cancer [1]. It infects approximately $50 \%$ of individuals worldwide. In Vietnam, the prevalence of $H$. pylori is very high (75\%) [2]. The rates of $H$. pylori infection in Vietnamese patients with chronic gastritis, gastric ulcers, duodenal ulcers and gastroduodenal ulcers range from $59.9-69.9 \%, 77.8 \%, 85 \%-95 \%$, and $85.3 \%-93.6 \%$, respectively [3]. The incidence of gastric cancer in Vietnam has been reported to be the highest compared to other southeast Asian countries [4]. Successful $H$. pylori eradication has been demonstrated to not only heal peptic ulcers but also prevent their recurrence and reduce the incidence of gastric cancer $[3,5]$.

Amoxicillin is one of the key antibiotics often used to eradicate $H$. pylori in standard triple therapy (amoxicillin, clarithromycin and proton pump inhibitor) as the first-line treatment [6]. However, the spread of amoxicillin- and/or clarithromycin-resistant $H$. pylori has become an important cause of eradication failure. A high rate of clarithromycin resistance of $H$. pylori $(72.6 \%)$ has been well documented in Vietnam [7]. Additionally, recent data in Vietnam have shown that the amoxicillin resistance rate of $H$. pylori differs across regions and it seems to have increased over time, from $1.1 \%$ in 2015 to $10.4 \%$ in 2016 and $15 \%$ in $2018[3,8,9]$. This threatens the effectiveness of $H$. pylori eradication therapies with these antibiotics.

Point mutations in the genes coding for penicillin-binding proteins (PBPs) leads to a decreased affinity for the drug and results in amoxicillin resistance $[10,11]$. Among these genes, the $p b p 1 A$ gene seems to be one of the keys [12-15]. There have been several studies on the molecular antibiotic resistance of $H$. pylori in Vietnam, but most of them focused on clarithromycin and levofloxacin resistance $[7,9,16]$. This is the first study conducted to investigate the molecular mechanism of amoxicillin resistance in $\mathrm{H}$. pylori in Vietnam.

The present study aimed to evaluate the prevalence of amoxicillin-resistant $H$. pylori-positive gastric biopsy specimens and to investigate point mutations in the $p b p 1 \mathrm{~A}$ gene in $\mathrm{H}$. pylori-sensitive and primaryresistant samples. This study contributes to uncovering novel point mutations in the $p b p 1 A$ gene underlying this resistance effect.

\section{Materials And Methods}

\section{Patient population and clinical specimens}

This study was conducted between January 2019 and April 2021 at the University Medical Center, Ho Chi Minh City, Vietnam. Vietnamese patients presenting with naive dyspepsia and aged $\geq 18$ years were recruited. The exclusion criteria included patients with gastric cancer and/or those who took any antibiotics within the last 4 weeks.

The sample size was calculated by RaoSoft ${ }^{\circledR}$ software (http://www.raosoft.com/samplesize.html) at a $95 \%$ confidence level and alpha set at 0.05 . During upper gastrointestinal endoscopy, four biopsies were obtained from each patient. A total of 308 gastric biopsy specimens were collected through endoscopy. The first pair of specimens (one from the antrum and one from the corpus) was tested using both the 
rapid urease test (NK-Pylori test, Nam Khoa Biotek Co., Ltd.) and a polymerase chain reaction-based test (PCR) (AccuPid H. pylori Genotyping Kit, ref. No. Q01HPY03.1A, Khoa Thuong Biotech Co., Ltd.). The second pair was stored in transport medium [17] and kept at $2-8^{\circ} \mathrm{C}$ until processed for culture within 3 hours after sampling. A total of 101 samples were collected for culture. The samples can also be stored at $-80^{\circ} \mathrm{C}$ in $\mathrm{BHI}(\mathrm{BD})$ supplemented with $25 \%$ glycerol until culture. The $\mathrm{Pbp} 1 \mathrm{~A}$ gene fragment from all samples was subjected to direct sequencing. The patient characteristics are presented in Table 1.

\section{Culture conditions and bacteria identification}

Gastric biopsy specimens with a positive rapid urease test were collected and maintained for a maximum of 3 hours in transport medium [17] until further processing. The samples were then ground in $100 \mu \mathrm{L}$ brain heart infusion (BHI, BD) broth supplemented with $10 \%$ foetal bovine serum (FBS, Sigma-Aldrich) and cultured on Columbia agar (BD) plates supplemented with $10 \%$ lysed sheep blood (Nam Khoa Biotek Co., Ltd.), $1 \%$ isovitexin (BD), a skin antibiotic mixture (Sigma-Aldrich), and $2.5 \mu \mathrm{g} / \mathrm{mL}$ amphotericin B (Sigma-Aldrich). Plates were incubated for $4-5$ days at $37^{\circ} \mathrm{C}$ in a microaerobic atmosphere. A single colony of a 4-5-day-old culture was identified through morphological observation, urease tests and PCR specific to the cagA and vacA genes. A colony with specific morphology, a positive urease test and identified $\operatorname{cag} A$ and $\operatorname{vac} A$ was subcultured on Columbia agar plates as described above for 4 days. Amplification and detection of the cagA and $v a c A$ genes was performed based on a previously published protocol [18].

\section{Determination of the Minimal Inhibitory Concentration}

The minimal inhibitory concentration (MIC) of amoxicillin was determined by the E-test method (BioMerieux, ref\# 412243). H. pylori strains stored at $-80^{\circ} \mathrm{C}$ were thawed on Columbia agar plates supplemented with $10 \%$ lysed sheep blood and $1 \%$ Isovitalex and incubated at $37^{\circ} \mathrm{C}$ for $3-4$ days in a microaerobic atmosphere. Colonies were subcultured on another plate for 3 more days. Each plate was swabbed with a sterile cotton-tipped applicator, and the cells were suspended in BHI to obtain a turbidity equivalent to a 3.0 McFarland standard. A $100 \mu$ bacterial suspension was inoculated on a Columbia plate containing $10 \%$ lysed sheep blood and $1 \%$ isovitalex, and another sterile cotton-tipped swab was used to streak in three directions across the plate. The plates were left to dry for 2-3 min, and then the Etest strips containing a continuous exponential gradient of amoxicillin were placed on the agar surface. The plates were incubated at $37^{\circ} \mathrm{C}$ for 3-4 days in a microaerobic atmosphere. At the end of the incubation period, the MICs were determined by the intercept of the zones of growth inhibition with the graded E-test strip. The reference H. pylori strain ATCC ${ }^{\circledR} 43504^{\mathrm{TM}}$ susceptible to amoxicillin $\left(\mathrm{Amx}{ }^{\mathrm{S}}\right)$ was always used as a quality control strain, and MIC determination was accepted only if the MIC of amoxicillin for this strain was less than or equal to $0.125 \mu \mathrm{g} / \mathrm{ml}$. The susceptibility of the $H$. pylori isolates to amoxicillin was classified as resistant if the MIC was greater than $0.125 \mu \mathrm{g} / \mathrm{ml}$, according to the European Committee on Antimicrobial Susceptibility Testing (EUCAST) breakpoints (https://eucast.org/clinical_breakpoints/).

\section{Direct sequencing of the pbp1A gene fragment}


Total genomic DNA was extracted from the gastric biopsy specimens using a Qiacube automated purification system and kit (QIAGEN) according to the manufacturer's standard instructions. Optimisation of the real-time PCR components and conditions was performed to determine the optimal conditions for the amplification of a specific fragment of the $p b p 1 A$ gene of the bacteria in an automated thermal cycler (Roto-Gene Q, Qiagen). Sequences of the pbp1A primers were designed in this study as follows: pbp1A-F: 5'-CGATAGATTTGGATTACCAACGC-3'; pbp1A-R: 5'-ACGATTTCTTTACGCAAGCC-3'. The size of the expected amplicon was $1035 \mathrm{bp}$. The pbp1A-F/R primers (300 nM), $\mathrm{MgCl}_{2}(1 \mathrm{mM}), \mathrm{h}-\mathrm{Taq}$ DNA polymerase (2 units), dNTP mix (0.2 mM), 1X PCR buffer, 1 X EvaGreen and $5 \mu$ l of the extracted DNA were used in a total reaction volume of $25 \mu \mathrm{l}$. The optimal amplification of the target DNA was set at $95^{\circ} \mathrm{C}$ for $15 \mathrm{~min}$, followed by 40 cycles of denaturation at $95^{\circ} \mathrm{C}$ for $30 \mathrm{sec}$, annealing at $60^{\circ} \mathrm{C}$ for $30 \mathrm{sec}$ and extension at $72^{\circ} \mathrm{C}$ for $1 \mathrm{~min}$. After amplification, the samples were denatured at $95^{\circ} \mathrm{C}$ for $30 \mathrm{sec}$ and cooled to $65^{\circ} \mathrm{C}$, where they were held at that temperature for $30 \mathrm{sec}$. Then, the samples were slowly heated to $95^{\circ} \mathrm{C}$ at a ramping rate of $0.5^{\circ} \mathrm{C} / \mathrm{s}$ with continuous acquisition of the decline in fluorescent value. Melting curves were plotted automatically and analysed with Roto-Gene $\mathrm{Q}$ software. The specific melting temperature $(\mathrm{Tm})$ of the pbp1A PCR products was $87.2 \pm 0.2^{\circ} \mathrm{C}$.

The PCR products were purified with ethanol. The purified products were sequenced using a BigDye ${ }^{T M}$ Terminator v3.1 Cycle Sequencing kit (Applied Biosystems, Foster City, CA). The sequencing PCR products were purified with the BigDye XTerminator ${ }^{\text {TM }}$ and read in an ABI 3130 Genetic Analyser. Nucleotide sequences of both chains obtained were aligned and transformed into amino acid sequences using Geneious Prime software version 2021.1.1 (Auckland, New Zealand) and compared to the sequences of strains 26695 (AE000511) and Hargenberg (AF479617) deposited in GenBank (http://www.ncbi.nlm.nih.gov/Genbank/) for detection of mutations in the pbp1A gene.

\section{Statistical analysis}

Statistical analysis was performed using the Statistical Package for Social Science (SPSS) version 20.0. Descriptive statistical analysis was used to describe the characteristics of the patients' gender, age, residency, gastric disease status and susceptibility to amoxicillin of the strains isolated from the clinical samples. A one-sample binomial test was used to determine whether the proportion of cases (sex, amoxicillin resistance, coinfection) was equal to the previously documented corresponding proportion. The chi-square test was used to correlate the presence of mutations in the pbp1A gene and the susceptibility to amoxicillin. Fisher's exact test was used alternatively when more than $20 \%$ of the expected counts were less than 5 . Monte Carlo estimates of the exact significance were used when the data did not meet the assumption of the asymptotic method. A p-value less than 0.05 was considered significant.

\section{Results}

\section{Demographic characteristics}


There were 308 qualified patients recruited in this study. Details on the demographic characteristics of these patients are presented in Table 1.

There were $46.1 \%$ (142/308; 95\% Cl: 40.3-51.6) men and 53.9\% (166/308; 95\% Cl: 48.4-59.7\%) women. The gender ratio occurred with probabilities of 0.5 and $0.5(p=0.190 ;$ binomial test). The mean age of the patients was $40.5 \pm 11.4$ (95\% Cl: 39.2-41.8) years, ranging from 18-74. Age followed a normal distribution ( $p=0.247$; skewness test). The highest percentage of patients was from Ho Chi Minh City (31.5\%). The proportions of patients from nearby regions, including the southeastern area, Mekong River Delta, and central region, were similar, with proportions of $19.5 \%, 22.1 \%$ and $25.3 \%$, respectively; a very small percentage of patients (1.6\%) were from the Red River Delta. Most patients were diagnosed with gastritis $(93.5 \% ; 288 / 308)$, and only a small percentage of them were diagnosed with gastric ulcers $(6.5 \%$; 20/308). 
Table 1

Demographic characteristics and diagnosis of the recruited patients

\begin{tabular}{|c|c|c|}
\hline Characteristics & Number of cases $(n)$ & Rate (\%) \\
\hline \multicolumn{3}{|l|}{ Gender } \\
\hline Male & 142 & 46.1 \\
\hline Female & 166 & 53.9 \\
\hline Mean age \pm SD (range) (year) & $40.5 \pm 11.4(18-74)$ & \\
\hline \multicolumn{3}{|l|}{ Residency } \\
\hline Ho Chi Minh & 97 & 31.5 \\
\hline Southeast & 60 & 19.5 \\
\hline Mekong River Delta & 68 & 22.1 \\
\hline Central & 78 & 25.3 \\
\hline Red River Delta & 5 & 1.6 \\
\hline \multicolumn{3}{|l|}{ Diagnosis } \\
\hline Gastritis & 288 & 93.5 \\
\hline Gastric ulcer & 20 & 6.5 \\
\hline \multicolumn{3}{|l|}{ E-test for amoxicillin } \\
\hline Sensitive & 75 & 74.3 \\
\hline Resistant & 26 & 25.7 \\
\hline \multicolumn{3}{|c|}{$\begin{array}{l}\text { Amoxicillin MIC was determined randomly in } 101 \text { samples ( } 32.8 \% \text { of the entire study group). Among } \\
\text { these samples, } 74.3 \% \text { ( }(75 / 101) \text { of strains were sensitive, and } 25.7 \%(26 / 101) \text { of strains were primarily } \\
\text { resistant to amoxicillin. The isolates with phenotypic resistance to amoxicillin exhibited a MIC range } \\
\text { of } 0.190-1.5 \mathrm{mg} / \mathrm{I} \text { (Figure } 1) \text {. }\end{array}$} \\
\hline
\end{tabular}

\section{Virulence factors of $\mathrm{H}$. pylori}

The presence of the cagA or vacA gene was investigated in all 308 clinical specimens positive for the rapid urease test. Based on the vacA genotypes, coinfection was discovered: 38 (12.3\%) specimens were colonised by at least two H. pylori strains (vacA $\mathrm{m} 1$ and vacA $\mathrm{m} 2$ ). All of the coinfection specimens were excluded from the analysis to assess the association between bacterial genotypes and clinical outcome as well as antibiotic resistance.

The cagA gene was present in $225(83.3 \%)$ of the $270 \mathrm{H}$. pylori specimens. There was no association between gastritis and peptic ulcers with the presence or absence of the cagA gene $(p=1.000)$. 
Regarding the vacA genotypes, most of the specimens had the vacAs 1 allele (98.4\%). No association was detected between the vacA signal sequences and the clinical outcome $(p=0.265)$. However, there was a relationship between the vacA middle sequences and the clinical outcome $(p=0.021)$. The vacA $\mathrm{m} 1$ allele was found to be significantly higher in 12 (75.0\%) specimens from gastric ulcer patients, and the vacA $\mathrm{m} 2$ allele was significantly higher in 141 (55.5\%) of the specimens from gastritis patients. The combination of the vacA signal and middle sequences with the clinical outcome also presented a similar significant relationship $(\mathrm{p}=0.008)$. VacA s $1 \mathrm{~m} 1$ was higher in the ulcer group $(75.0 \%)$, while vacA s $1 \mathrm{~m} 2$ was higher in the gastritis group (53.9\%). The combination of $c a g A$ status and $v a c A$ genotypes was also investigated. There was an association between the combined genotypes and the clinical outcome $(p=$ 0.032). In particular, no association was observed between the genotypes and the resistance to amoxicillin $(p>0.05)$ (Table 2). 
Table 2

The genotypes of the H. pylori strains and the clinical outcome

\begin{tabular}{|c|c|c|c|c|c|c|}
\hline \multirow[t]{3}{*}{ Genotype } & \multicolumn{3}{|c|}{ Clinical outcome } & \multicolumn{3}{|c|}{ Amoxicillin susceptibility } \\
\hline & Gastritis & Gastric ulcer \% $(n=16)$ & $\mathbf{p}$ & Resistant & Sensitive & $\mathbf{p}$ \\
\hline & $\%(n=254)$ & & value & $\%(n=19)$ & $\%(n=66)$ & value \\
\hline \multicolumn{7}{|l|}{$\operatorname{cag} A$} \\
\hline $\operatorname{cag} A^{+}$ & $83.1(211)$ & $87.5(14)$ & \multirow[t]{2}{*}{1.000} & $78.9(15)$ & $80.3(53)$ & \multirow[t]{2}{*}{1.000} \\
\hline $\operatorname{cag} A^{-}$ & $16.9(43)$ & $12.5(2)$ & & $21.1(4)$ & $19.7(13)$ & \\
\hline \multicolumn{7}{|l|}{$\operatorname{vac} A$} \\
\hline s1 & $98.4(250)$ & $93.8(15)$ & \multirow[t]{2}{*}{0.265} & $94.7(18)$ & $97.0(64)$ & \multirow[t]{2}{*}{0.537} \\
\hline s2 & $1.6(4)$ & $6.2(1)$ & & $5.3(1)$ & $3.0(2)$ & \\
\hline $\mathrm{m} 1$ & $44.5(113)$ & $75.0(12)$ & \multirow[t]{2}{*}{0.021} & $68.4(13)$ & $43.9(29)$ & \multirow[t]{2}{*}{0.060} \\
\hline $\mathrm{m} 2$ & $55.5(141)$ & $25.0(4)$ & & $31.6(6)$ & $56.1(37)$ & \\
\hline s1m1 & $44.5(113)$ & $75.0(12)$ & \multirow[t]{3}{*}{0.008} & $68.4(13)$ & $43.9(29)$ & \multirow[t]{3}{*}{0.086} \\
\hline $\mathrm{s} 1 \mathrm{~m} 2$ & $53.9(137)$ & $18.8(3)$ & & $26.3(5)$ & $53.0(35)$ & \\
\hline $\mathrm{s} 2 \mathrm{~m} 2$ & $1.6(4)$ & $6.2(1)$ & & $5.3(1)$ & $3.0(2)$ & \\
\hline \multicolumn{7}{|l|}{$\operatorname{cag} A$ and $\operatorname{vac} A$} \\
\hline $\operatorname{cag} A^{+} \operatorname{vac} A \mathrm{~s} 1 \mathrm{~m} 1$ & $42.1(107)$ & $68.8(11)$ & \multirow[t]{6}{*}{0.032} & $63.2(12)$ & $40.9(27)$ & \multirow[t]{6}{*}{0.235} \\
\hline $\operatorname{cag}^{+} \operatorname{vac} A \mathrm{~s} 1 \mathrm{~m} 2$ & $40.2(102)$ & $18.8(3)$ & & $15.8(3)$ & $37.9(25)$ & \\
\hline $\operatorname{cag} A^{+}$vacA s $2 \mathrm{~m} 2$ & $0.8(2)$ & $0.0(0)$ & & $0.0(0)$ & $1.5(1)$ & \\
\hline $\operatorname{cagA}^{-}$vacA s1m1 & $2.4(6)$ & $6.2(1)$ & & $5.3(1)$ & $3.0(2)$ & \\
\hline $\operatorname{cag}^{-}$vacA s $1 \mathrm{~m} 2$ & $13.8(35)$ & $0.0(0)$ & & $10.5(2)$ & $15.2(10)$ & \\
\hline $\operatorname{cag} A^{-}$vacA s $2 \mathrm{~m} 2$ & $0.8(2)$ & $6.2(1)$ & & $5.3(1)$ & $1.5(1)$ & \\
\hline
\end{tabular}

Amoxicillin resistance in $A m x^{R} H$. pylori isolates is mediated by mutations in the $p b p 1 A$ gene [13]. To investigate the genetic diversity of $p b p 1 A$ genes in this study by gene sequencing, the $p b p 1 A$ gene sequences of the H. pylori reference strain $26695\left(025319, \mathrm{Amx}^{\mathrm{S}}\right.$ ) and Hargenberg (AF479617, Amx $\mathrm{x}^{\mathrm{R}}$ ) were used as controls to compare and number the isolates according to the corresponding deduced 
amino acid sequences. A total of 270 sequences of pbp $1 A$ gene fragments spanning amino acids $310-$ 596 were analysed. The results showed that the proportion of amino acid substitutions varied from 0.4$100 \%$ depending on the amino acid position (Figure 2). Several amino acid positions in the acyl transpeptidase domain of PBP1A had a high proportion of substitutions, such as Asp $_{535}$ to Asn (100\%), $\operatorname{Ser}_{589}$ to Gly (96.7\%), Asp 479 to Glu (86.6\%), and Asn $_{504}$ to Asp (74.1\%). Amino acid positions with substitution proportions equal to or lower than $1 \%$ are not shown on the graph (Figure 2).

\section{Association between amino acid substitution and amoxicillin susceptibility}

To investigate which pbp1A gene mutations were involved in amoxicillin resistance in the $A m o x^{R}$ isolates in this study, we evaluated all 77 amino acid substitutions in the acyl transpeptidase domain of PBP-1A, from amino acids 310 to 596 . Seven amino acid changes were found to be significantly different between the Amox ${ }^{S}$ and Amox ${ }^{R}$ samples (Table 3), including Phe 366 to Leu ( $\left.\mathbb{Z}^{2}=19.055 ; p<0.001\right), S_{414}$ to $\operatorname{Arg}$ $\left(\nabla^{2}=31.056 ; p<0.001\right), \mathrm{Glu} / \mathrm{Asn}_{464-465}\left(\mathbb{\nabla}^{2}=6.898 ; p=0.009\right), \mathrm{Val}_{469}$ to Met $\left(\mathbb{\nabla}^{2}=7.304 ; p=0.021\right)$, $\mathrm{Phe}_{473}$ to Val $\left(\mathbb{\nabla}^{2}=21.223 ; p<0.001\right), \mathrm{Asp}_{479}$ to Glu ( $\left.\mathbb{\nabla}^{2}=4.060 ; p=0.044\right)$, and Ser/Ala/Gly $595-596$ ( $\mathbb{\nabla}^{2}=$ 10.356; $p=0.001$ ). In particular, two novel insertion mutations, Glu/Asn ${ }_{464-465}$ and Ser/Ala/Gly ${ }_{595-596 \text {, }}$ were discovered for the first time in this study, together with changes in $\mathrm{Val}_{469}$ to Met and $\mathrm{Asp}_{479}$ to Glu. These four novel, never-reported mutations were in or adjacent to the second $\left(\mathrm{SKN}_{402-404}\right)$ and third $\left(K_{T G_{555-557}}\right)$ conserved PBP motifs. The other three mutations, including Phe 366 to Leu, $\mathrm{Ser}_{414}$ to Arg, and $\mathrm{Phe}_{473}$ to $\mathrm{Val}$, have been documented $[11,13,15]$.

We noticed that the previously described amino acid changes, such as $\mathrm{Glu}_{406}$ to Ala $\left(\mathbb{\nabla}^{2}=0.017 ; p=\right.$ 1.000), Ser 417 to $\operatorname{Thr}\left(\mathbb{\nabla}^{2}=0.291 ; p=1.000\right), \operatorname{Thr}_{556}$ to Ser $\left(\mathbb{\nabla}^{2}=0.895 ; p=1.000\right)$, and $\operatorname{Asn}_{562}$ to $\operatorname{Tyr}\left(\mathbb{Z}^{2}=\right.$ 4.338; $p=0.072$ ), associated with a high level of beta-lactam resistance in acquired multidrug-resisting $H$. pylori [19] were insignificant in this population (Table 3). Additionally, other novel amino acid substitutions mentioned previously [13] in selected $A m x^{R}$ transformants comprising $\mathrm{Thr}_{540}$ to $l l e, \mathrm{Ser}_{542}$ to $A r g, T r_{555}$ to Ser, and $A_{s n_{561}}$ to Tyr were unchanged in this study. The results showed that several mutated positions had statistical significance between amoxicillin-sensitive and amoxicillin-resistant samples and were completely different from amino acid positions reported to be related to amoxicillin resistance published previously [15]. These mutations are adjacent to the second and third PBP motifs, which were observed only in $A m x^{R} H$. pylori colonies after transformation [13]. 
Table 3

Relationships between amino acid substitution and amoxicillin susceptibility

\begin{tabular}{|c|c|c|c|c|c|c|}
\hline Position & Amino acid & Genotype & Resistant & Sensitive & $x^{2}$ & $p$ value \\
\hline \multirow[t]{2}{*}{315} & Glu & $\mathrm{mt}$ & 9 & 20 & \multirow[t]{2}{*}{2.312} & \multirow[t]{2}{*}{0.128} \\
\hline & Lys & wt & 8 & 41 & & \\
\hline \multirow[t]{2}{*}{366} & Leu & $\mathrm{mt}$ & 15 & 16 & \multirow[t]{2}{*}{19.055} & \multirow[t]{2}{*}{$<0.001$} \\
\hline & Phe & wt & 4 & 50 & & \\
\hline \multirow[t]{2}{*}{406} & Ala & $\mathrm{mt}$ & 1 & 3 & \multirow[t]{2}{*}{0.017} & \multirow[t]{2}{*}{$1.000^{*}$} \\
\hline & Glu & wt & 18 & 63 & & \\
\hline \multirow[t]{2}{*}{414} & Arg & $\mathrm{mt}$ & 15 & 9 & \multirow[t]{2}{*}{31.056} & \multirow[t]{2}{*}{$<0.001^{*}$} \\
\hline & Ser & wt & 4 & 57 & & \\
\hline \multirow[t]{2}{*}{417} & Thr & $\mathrm{mt}$ & 0 & 1 & \multirow[t]{2}{*}{0.291} & \multirow[t]{2}{*}{$1.000^{*}$} \\
\hline & Ser & wt & 19 & 65 & & \\
\hline \multirow[t]{2}{*}{ Ins 464-465 } & Glu/Asn & $\mathrm{mt}$ & 11 & 17 & \multirow[t]{2}{*}{6.898} & \multirow[t]{2}{*}{0.009} \\
\hline & - & wt & 8 & 49 & & \\
\hline \multirow[t]{2}{*}{469} & Met & $\mathrm{mt}$ & 4 & 2 & \multirow[t]{2}{*}{7.304} & \multirow[t]{2}{*}{$0.021^{*}$} \\
\hline & Val & wt & 15 & 64 & & \\
\hline \multirow[t]{2}{*}{473} & Val & $\mathrm{mt}$ & 16 & 17 & \multirow[t]{2}{*}{21.223} & \multirow[t]{2}{*}{$<0.001^{\prime}$} \\
\hline & Phe & wt & 3 & 49 & & \\
\hline \multirow[t]{2}{*}{474} & Val & $\mathrm{mt}$ & 0 & 5 & \multirow[t]{2}{*}{1.529} & \multirow[t]{2}{*}{$0.583^{\star}$} \\
\hline & Ala & wt & 19 & 61 & & \\
\hline \multirow[t]{2}{*}{479} & Glu & $\mathrm{mt}$ & 13 & 58 & \multirow[t]{2}{*}{4.060} & \multirow[t]{2}{*}{0.044} \\
\hline & Asp & wt & 6 & 8 & & \\
\hline \multirow[t]{2}{*}{504} & Asn & $\mathrm{mt}$ & 14 & 53 & \multirow[t]{2}{*}{0.387} & \multirow[t]{2}{*}{0.534} \\
\hline & Asp & wt & 5 & 13 & & \\
\hline 508 & Asn & $\mathrm{mt}$ & 6 & 16 & 0.414 & 0.520 \\
\hline & Asp & wt & 13 & 50 & & \\
\hline 509 & Ile & $\mathrm{mt}$ & 6 & 12 & 1.586 & 0.208 \\
\hline
\end{tabular}




\begin{tabular}{|c|c|c|c|c|c|c|}
\hline Position & Amino acid & Genotype & Resistant & Sensitive & $x^{2}$ & $p$ value \\
\hline & Val & wt & 13 & 54 & & \\
\hline \multirow[t]{2}{*}{515} & lle & $\mathrm{mt}$ & 10 & 41 & \multirow[t]{2}{*}{0.554} & \multirow[t]{2}{*}{0.457} \\
\hline & Met & wt & 9 & 25 & & \\
\hline \multirow[t]{2}{*}{543} & Arg & $\mathrm{mt}$ & 5 & 17 & \multirow[t]{2}{*}{0.002} & \multirow[t]{2}{*}{0.961} \\
\hline & Ser & wt & 14 & 49 & & \\
\hline \multirow[t]{2}{*}{556} & Ser & $\mathrm{mt}$ & 0 & 3 & \multirow[t]{2}{*}{0.895} & \multirow[t]{2}{*}{$1.000^{\star}$} \\
\hline & Thr & wt & 19 & 63 & & \\
\hline \multirow[t]{2}{*}{562} & Tyr & $\mathrm{mt}$ & 3 & 2 & \multirow[t]{2}{*}{4.338} & \multirow[t]{2}{*}{$0.072^{*}$} \\
\hline & Asn & wt & 16 & 64 & & \\
\hline \multirow[t]{2}{*}{589} & Gly & $\mathrm{mt}$ & 19 & 62 & \multirow[t]{2}{*}{1.208} & \multirow[t]{2}{*}{$0.571^{*}$} \\
\hline & Ser & wt & 0 & 4 & & \\
\hline \multirow[t]{2}{*}{593} & Ala & $\mathrm{mt}$ & 4 & 12 & \multirow[t]{2}{*}{0.080} & \multirow[t]{2}{*}{$0.784^{*}$} \\
\hline & Thr & wt & 15 & 54 & & \\
\hline \multirow[t]{2}{*}{595} & Ser & $\mathrm{mt}$ & 3 & 12 & \multirow[t]{2}{*}{0.058} & \multirow[t]{2}{*}{$1.000^{*}$} \\
\hline & Gly & wt & 16 & 54 & & \\
\hline \multirow[t]{2}{*}{ Ins 595-596 } & Gly/Ser/Ala & $\mathrm{mt}$ & 14 & 21 & \multirow[t]{2}{*}{10.356} & \multirow[t]{2}{*}{0.001} \\
\hline & - & wt & 5 & 44 & & \\
\hline \multirow[t]{2}{*}{596} & Ile/Ala & $\mathrm{mt}$ & 1 & 1 & \multirow[t]{2}{*}{0.878} & \multirow[t]{2}{*}{$0.403^{*}$} \\
\hline & Val & wt & 18 & 64 & & \\
\hline
\end{tabular}

\section{Phylogenetic analyses of the pbp1A sequences}

Phylogenetic analyses were performed on all $p b p 1 A$ gene fragment sequences to determine whether the sequences with identified mutations were in the same group of sequences related to amoxicillin resistance. Trees were constructed from 85 sequences based on the pbp1A amplification fragments trimmed to 879 bp by the Tamura-Nei genetic distance model and the neighbour-joining tree building method (Geneious Prime ${ }^{\circledR}$ 2021.1.1). This primary phylogenetic analysis suggested that the $p b p 1 A$ sequences obtained in the present study might belong to different sequence groups. The sequences from which $H$. pylori isolates showed resistance to amoxicillin could be combined into two groups with close relatedness to those from which $H$. pylori isolates were sensitive to amoxicillin, except for samples A003, 
$A 075, A 138$ and $A 163$. These two groups $(a, b)$ also shared the most recent common ancestor of the pbp1A gene (Figure 3).

Table 4 shows that groups (a) and (b) had very similar amino acid substitution and insertion profiles and were quite different from the reference sequences at the seven observed positions. There were four novel strains from our samples presenting single amino acid substitutions at $\mathrm{LeU}_{366}$ and $\mathrm{Val}_{473}$, as well as

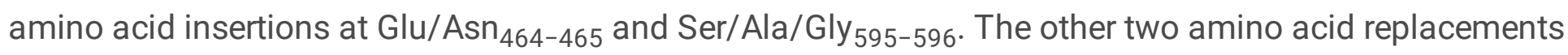
$\left(\mathrm{Met}_{469}\right.$ and $\mathrm{Glu}_{479}$ ) also appeared uniquely in our data when compared to the references. However, the presence of specific substitutions and insertions was present not only in the resistant samples but also in the sensitive samples.

Table 4

Overview of amino acid differences in PBP1A proteins occurring in clinical samples with resistance and sensitivity to amoxicillin.

\begin{tabular}{|c|c|c|c|c|c|c|c|c|c|}
\hline \multirow{2}{*}{$\begin{array}{l}\text { Sequence } \\
\text { groups }\end{array}$} & \multirow{2}{*}{$\begin{array}{l}\text { E-test for } \\
\text { Amoxicillin }^{b}\end{array}$} & \multirow[t]{2}{*}{ Clinical samples } & \multicolumn{7}{|c|}{ Amino acid position ${ }^{a}$} \\
\hline & & & 366 & 414 & $\operatorname{lns} 1^{c}$ & 469 & 473 & 479 & $\operatorname{lns} 2^{d}$ \\
\hline \multirow[t]{5}{*}{ Group (a) } & \multirow[t]{2}{*}{$\begin{array}{l}0.047- \\
0.125\end{array}$} & \multirow{2}{*}{$\begin{array}{l}\text { A283, A407, A105, } \\
\text { A186, A146, A207, } \\
\text { A271, A142, A481 }\end{array}$} & \multirow[t]{2}{*}{ Leu } & \multirow{2}{*}{$\begin{array}{l}\text { Ser } \\
\text { Arg }\end{array}$} & \multirow[t]{2}{*}{ Glu } & \multirow[t]{2}{*}{ Val } & \multirow[t]{2}{*}{ Val } & \multirow[t]{2}{*}{ Glu } & Ser \\
\hline & & & & & & & & & Gly \\
\hline & \multirow{3}{*}{$\begin{array}{l}0.190- \\
1.000\end{array}$} & \multirow{3}{*}{$\begin{array}{l}\text { A132, A009, A234, } \\
\text { A482, A102, A100 }\end{array}$} & \multirow[t]{3}{*}{ Leu } & Ser & Lys & Val & \multirow[t]{3}{*}{ Val } & Glu & Ser \\
\hline & & & & Arg & Glu & Met & & Asp & Gly \\
\hline & & & & & - & & & & Val \\
\hline \multirow[t]{5}{*}{ Group (b) } & \multirow{2}{*}{$\begin{array}{l}0.032- \\
0.125\end{array}$} & \multirow{2}{*}{$\begin{array}{l}\text { A119, A312, A404, } \\
\text { A334 }\end{array}$} & \multirow[t]{2}{*}{ Leu } & & \multirow[t]{2}{*}{ Glu } & \multirow[t]{2}{*}{ Val } & \multirow[t]{2}{*}{ Val } & \multirow[t]{2}{*}{ Glu } & Ser \\
\hline & & & & Arg & & & & & Gly \\
\hline & \multirow{3}{*}{$\begin{array}{l}0.190- \\
2.000\end{array}$} & \multirow{3}{*}{$\begin{array}{l}\text { A147, A124, A277, } \\
\text { A353, A162, A298, } \\
\text { A255, A005, A141, } \\
\text { A182 }\end{array}$} & \multirow[t]{3}{*}{ Leu } & \multirow[t]{3}{*}{ Arg } & Lys & Val & \multirow[t]{3}{*}{ Val } & Glu & Ser \\
\hline & & & & & Glu & Met & & Asp & Gly \\
\hline & & & & & \multicolumn{2}{|l|}{-} & & & Val \\
\hline 26695 & Sensitive & - & Phe & Ser & - & Val & Phe & Asp & - \\
\hline Hagenberg & Resistant & - & Phe & Arg & - & Val & Phe & Asp & - \\
\hline $\begin{array}{l}\text { a Positions } \\
\text { pylori Hage } \\
\text { acid inserte }\end{array}$ & $\begin{array}{l}\text { mino acid di } \\
\text { rg (AF47961 } \\
\text { tween positi }\end{array}$ & $\begin{array}{l}\text { erences are given to } \\
\text {; }{ }^{\circ} \mathrm{mg} / \mathrm{l} ;{ }^{c} \text { Amino ac } \\
\text { is } 595 \text { and } 596 \text {. }\end{array}$ & e rela & ves & poir & f the & b1A & e of & mino \\
\hline
\end{tabular}

\section{Discussion}


Amoxicillin resistance in $\mathrm{H}$. pylori is one of the greatest concerns of clinicians because anti-H. pylori regimens often consist of amoxicillin in addition to other antibiotics and proton pump inhibitors [20,21]. Recent studies have suggested that amoxicillin resistance in $H$. pylori results from alterations in PBP1A $[12,13,15,22]$. One of the main purposes of this study was to investigate the molecular mechanism of amoxicillin resistance in $H$. pylori strains collected from endoscopic biopsies in Vietnam.

The amoxicillin-resistant $H$. pylori proportion discovered in this study $(25.7 \%)$ was similar to the finding by Saniee et al. in Iran (27.1\%; p = 0.423) in 2018 [23] but significantly higher than that in other studies, such as Zerbetto et al. in Argentina $(7.6 \%, \mathrm{p}<0.001)$ in 2017 [15], Manal et al. in Egypt (18.3\%; $\mathrm{p}=0.035)$ in 2018 [24], Ortis et al. in Central America (10\%; p 0.001) in 2019 [25], Azzaya et al. in Mongolia (11.9\%; $\mathrm{p}<0.001)$, Aumpan et al. in Cambodia (0\%; < 0.001) in 2020 [26, 27], Calinga-Ponce et al. in Mexico $(1.8 \% ; p<0.001)$ and Li et al. in China $(0 \% ; p<0.001)$ in $2021[28,29]$. Compared to previous studies in Vietnam, the amoxicillin resistance proportion has been trending up significantly, for instance, from $0 \%$ ( $p$ $<0.001)$ in 2013 [30], 1.1\% ( $<$ < 0.001) in 2015 [8], 10.4\% ( < 0.001) in 2016 [9], 15\% ( $=0.002)$ in 2019 [3] and to $25.7 \%$ in 2020 for this study. Although the previous local studies were different from each other regarding geographical areas, sample sizes, study period and antimicrobial testing methods, an increasing proportion of amoxicillin resistance in H. pylori in Vietnam has been generally demonstrated, suggesting that this is a serious emerging threat to the success of amoxicillin-based regimens. The high rate of amoxicillin-resisting $\mathrm{H}$. pylori in our study might be explained by the fact that the combination of amoxicillin and clavulanate potassium is often empirically prescribed for various infectious diseases [31]. The incorrect use of antimicrobials can accelerate the selection of drug-resistant strains [23].

Multiple strains of $H$. pylorican coinfect the same patient [32]. The coinfection detected by vacA genotype in our study presented a rate of $12.3 \%$. A similar proportion in terms of coinfection determination was obtained when confirmed by random amplified polymorphic DNA (RAPD) fingerprinting (12.5\%; $p=0.500)$ [32] or through vacA and ice $A$ genotyping $(11.0 \% ; p=0.255)$ [33]. Therefore, coinfection needs to be excluded before evaluating the relationship between $H$. pylori genotypes and other factors, such as disease status and clinical symptoms, to maintain accuracy. Moreover, coinfection could undermine the success of eradication therapy and should be considered when interpreting the results of antimicrobial susceptibility tests [32].

Based on the $H$. pylori genotype analysis, our data showed an association between the $\operatorname{vac} A^{\mathrm{m} 1}$ genotype and gastric ulcers. This result suggests that individuals colonised with vac $A^{\mathrm{m} 1}$-positive $H$. pylori strains are at an increased risk of developing gastric ulcers. These results confirmed the $v a c A^{m 1}$ genotype is associated with an increased risk of peptic ulcers, which has been reported by Nguyen et al. [34] and Trang et al. [35] in Vietnam. Conversely, Milad et al. revealed that the $v a c A^{m 2}$ genotype was significantly higher in patients with peptic ulcer disease than in patients with gastritis in Iran [36]. On the other hand, several previous studies published by Godoy et al. in Brazil and Loivukene et al. in Estonia did not find any association between virulence factors such as $v a c A^{\mathrm{m} 1}$ genotype and clinical outcomes or bacterial resistance to metronidazole, although the coinfection by multiple strains has been well considered in 
these studies $[33,37]$. The difference in $c a g A$ and vacA genotype proportions as well as the association of these genotypes with the clinical outcomes might result from the fact that various populations have been evaluated with different ethnic groups and that a high genetic variability of strains in different countries exists $[38,39]$. However, there is universal agreement regarding the role of the $v a c A^{m 1}$ genotype among studies carried out in Vietnam at different time points. In addition, we did not find any association between the virulence factors and resistance to amoxicillin.

Amino acid substitutions in the acyl transpeptidase domain of PBP1A are required for resistance to amoxicillin $[12,13]$. However, other mechanisms could be involved in increasing the MIC value and contributing to the levels of high $A m x^{R}$ strains, such as decreasing membrane permeability due to altered porin proteins $(\mathrm{HopC}, \mathrm{HopH})$, increasing the activity of efflux pumps to eject antibiotics from the periplasm, or even reducing the binding of antibiotics to other PBPs, especially PBP2 $[19,40]$.

In this study, we discovered a high rate of resistance to amoxicillin. To identify the mutations of $p b p 1 \mathrm{~A}$ responsible for amoxicillin resistance, sequences of the pbp $1 A$ gene were analysed. We found seven amino acid changes possibly linked to amoxicillin resistance in clinical samples. Among them, the $\mathrm{Ser}_{414}$ to Arg substitution has been proven to be the main factor in amoxicillin resistance of the Hardenberg strain by site-directed mutagenesis [12] and it was also common in clinical Amx ${ }^{R}$ strains by natural transformation $[11,13]$. The $\mathrm{Phe}_{366}$ to Leu alteration was reported to be present in the clinical $A m x^{R}$ strain SZ79 in combination with the Ser $_{414}$ to Arg substitution [13]. Phe ${ }_{473}$ was recognised in strains sensitive to but less susceptible to amoxicillin but also in $A m x^{R}$ transformants in the absence of $S r_{414}$ to Arg substitutions [15], while $\mathrm{Val}_{473}$ was common in our $\mathrm{Amx}^{\mathrm{R}}$ samples in the context of $\mathrm{Ser}_{414}$ to $\mathrm{Arg}$ changes. Although it has become clear that amino acid variations conferring resistance vary by the geographical origins of the strains [15], these data have confirmed the combination of amino acid substitutions or mutations in multiple loci to amoxicillin resistance [13].

To investigate the relatedness, as well as the combination of different mutations of $p b p 1 A$ sequences in the resistance to amoxicillin, we created a phylogenetic tree of 85 obtained $p b p 1 A$ gene fragments. The grouping of the $p b p 1 A$ gene sequences suggested that there were other mechanisms in addition to the mutations in the pbp1A gene contributing to amoxicillin resistance in $H$. pylori in Vietnam. Other studies have also shown that distinct mechanisms of antimicrobial resistance also play important roles in the resistance to amoxicillin in $\mathrm{H}$. pylori [13].

Our study had several limitations. First, resistant mutations were not identified directly from isolates but only from gastric biopsy specimens. We excluded coinfection cases from the data analysis, and this approach might not be ideal for identifying the molecular mechanisms related to amoxicillin resistance. Second, the role of other genes that could have synergistic effects in amoxicillin resistance could not be excluded. We did not evaluate coinfection by multiple $H$. pylori strains by fingerprinting methods such as random amplified polymorphic DNA (RAPD) or multilocus sequence typing (MLST). Last but not least, 
resistance has not been confirmed to have a direct correlation with eradication efficacy in real-life practice.

However, the strength of this study is that it was conducted at one of the largest hospitals in southern Vietnam, which usually admits patients from Ho Chi Minh City and many nearby areas. This is the first study that reported mutations related to $\mathrm{Amx}^{\mathrm{R}} \mathrm{H}$. pylori in Vietnamese patients and it has identified some novel mutations, especially insertion mutations Glu/Asn ${ }_{464-465}$ and Ser/Ala/Gly ${ }_{595-596}$ in the pbp1A gene and other nearby mutations, which are likely specific to $H$. pylori strains in Vietnamese. Further studies are required to validate the role of these novel mutations in conferring amoxicillin resistance. In addition to the emerging prevalence of amoxicillin-resistant $H$. pylori strains, direct detection of $p b p 1 A$ gene mutations from $H$. pylori-positive biopsy specimens may lead to novel diagnostic strategies for amoxicillin resistance determination and would be useful in clinical practice. More importantly, other mechanisms, such as the acquisition or expression of $\beta$-lactamase or changes in other proteins involved in cell wall synthesis, such as PBP2, PBP3, and PBP4, should also be evaluated.

\section{Conclusion}

Our study has identified new mutations that are statistically associated with amoxicillin resistance and demonstrated the importance of the detection of amoxicillin-resistant Helicobacter pylori in clinical practice because of the emergence of these strains in Vietnam. However, further studies should be carried out to identify additional mechanisms contributing to amoxicillin resistance in $\mathrm{H}$. pylori.

\section{Declarations}

\section{Acknowledgements}

We highly appreciate support from University Medical Center 1 \& 2 in Ho Chi Minh City.

\section{Author's contributions}

TTT, ATN and NMC designed the experiment. TTT, MAT, LHQ, KTT, NQL, VVU, MNQV collected gastric biopsies and performed clinical diagnosis. ATN, DTHP, UTHN, ANTD, DTN and KDN conducted the experiment, analysed the samples and performed data analysis. ATN carried out data interpretation and produced the first draft of the manuscript. DTQ, TLT and VTN contributed to drafting and editing the manuscripts critically. All the authors have read and approved the final version of the manuscripts.

\section{Funding}

This study was supported by a research grant (reference number: 51/2019/HĐ-QPTKHCN) from the Department of Science and Technology Ho Chi Minh City (DOST HCMC) Vietnam.

\section{Availability of data and materials}


The detail data and materials available on request (anh.nt@umc.edu.vn).

\section{Ethics approval and consent to participate}

The study was approved by the ethics committees of the University of Medicine and Pharmacy at Ho Chi Minh City (reference number: 374/ĐHYD-HĐĐĐ, signed on 30/07/2019. All participants provided written informed consent. This work was carried out in accordance with the Code of Ethics of the World Medical Association (Declaration of Helsinki) for Experiments in Humans.

\section{Competing interests}

The authors declare that they have no competing interests.

\section{References}

1. Wroblewski LE, Peek RM, Jr., Wilson KT. Helicobacter pylori and gastric cancer: factors that modulate disease risk. Clin Microbiol Rev. 2010;23(4):713-39.

2. Rahman R, Asombang AW, Ibdah JA. Characteristics of gastric cancer in Asia. World J Gastroenterol. 2014;20(16):4483-90.

3. Khien VV, Thang DM, Hai TM, Duat NQ, Khanh PH, Ha DT, Binh TT, Dung HDQ, Trang TTH, Yamaoka Y. Management of antibiotic-resistant Helicobacter pylori infection: Perspectives from Vietnam. Gut Liver. 2019;13(5):483-497.

4. Quach DT, Vilaichone RK, Vu KV, Yamaoka Y, Sugano K, Mahachai V. Helicobacter pylori infection and related gastrointestinal diseases in Southeast Asian countries: An expert opinion survey. Asian Pac J Cancer Prev. 2018;19(12):3565-3569.

5. Lee YC, Chiang TH, Chou CK, Tu YK, Liao WC, Wu MS, Graham DY. Association between Helicobacter pylori eradication and gastric cancer incidence: A systematic review and meta-analysis. Gastroenterology. 2016;150(5):1113-1124 e5.

6. Malfertheiner P, Megraud F, O'Morain CA, Gisbert JP, Kuipers EJ, Axon AT, Bazzoli F, Gasbarrini A, Atherton J, Graham DY, Hunt R, Moayyedi P, Rokkas T, Rugge M, Selgrad M, Suerbaum S, Sugano K, El-Omar EM. Management of Helicobacter pylori infection-the Maastricht V/Florence Consensus Report. Gut. 2017;66(1):6-30.

7. Dang NQH, Ha TMT, Nguyen ST, Le NDK, Nguyen TMT, Nguyen TH, Pham TTH, Tran VH. High rates of clarithromycin and levofloxacin resistance of Helicobacter pylori in patients with chronic gastritis in the south east area of Vietnam. J Glob Antimicrob Resist. 2020;22:620-624.

8. Phan TN, Santona A, Tran VH, Tran TN, Le VA, Cappuccinelli P, Rubino S, Paglietti B. High rate of levofloxacin resistance in a background of clarithromycin- and metronidazole-resistant Helicobacter pylori in Vietnam. Int J Antimicrob Agents. 2015;45(3):244-8.

9. Quek C, Pham ST, Tran KT, Pham BT, Huynh LV, Luu NB, Le TK, Quek K, Pham VH. Antimicrobial susceptibility and clarithromycin resistance patterns of Helicobacter pylori clinical isolates in 
Vietnam. F1000Res. 2016;5:671.

10. Matteo MJ, Granados G, Olmos M, Wonaga A, Catalano M. Helicobacter pylori amoxicillin heteroresistance due to point mutations in PBP-1A in isogenic isolates. J Antimicrob Chemother. 2008;61(3):474-7.

11. Rimbara E, Noguchi N, Kawai T, Sasatsu M. Mutations in penicillin-binding proteins 1, 2 and 3 are responsible for amoxicillin resistance in Helicobacter pylori. J Antimicrob Chemother. 2008;61(5):995-8.

12. Gerrits MM, Schuijffel D, van Zwet AA, Kuipers EJ, Vandenbroucke-Grauls CM, Kusters JG. Alterations in penicillin-binding protein $1 \mathrm{~A}$ confer resistance to beta-lactam antibiotics in Helicobacter pylori. Antimicrob Agents Chemother. 2002;46(7):2229-33.

13. Gerrits MM, Godoy AP, Kuipers EJ, Ribeiro ML, Stoof J, Mendonca S, van Vliet AH, Pedrazzoli J, Jr., Kusters JG. Multiple mutations in or adjacent to the conserved penicillin-binding protein motifs of the penicillin-binding protein $1 \mathrm{~A}$ confer amoxicillin resistance to Helicobacter pylori. Helicobacter. 2006;11(3):181-7.

14. Paul R, Postius S, Melchers K, Schafer KP. Mutations of the Helicobacter pylori genes $r d x A$ and $p b p 1$ cause resistance against metronidazole and amoxicillin. Antimicrob Agents Chemother. 2001;45(3):962-5.

15. Zerbetto De Palma G, Mendiondo N, Wonaga A, Viola L, Ibarra D, Campitelli E, Salim N, Corti R, Goldman C, Catalano M. Occurrence of mutations in the antimicrobial target genes related to levofloxacin, clarithromycin, and amoxicillin resistance in Helicobacter pylori isolates from Buenos Aires City. Microb Drug Resist. 2017;23(3):351-358.

16. Tran VH, Ha TMT, Le PTQ, Phan TN, Tran TNH. Characterisation of point mutations in domain V of the 23S rRNA gene of clinical Helicobacter pylori strains and clarithromycin-resistant phenotype in Central Vietnam. J Glob Antimicrob Resist. 2019;16:87-91.

17. Blanchard TG, Nedrud JG. Laboratory maintenance of Helicobacter species. Curr Protoc Microbiol. 2012;Chapter 8:Unit8B 1.

18. Trung TT, Minh TA, Anh NT. Value of CIM, CLO test and multiplex PCR for the diagnosis of Helicobacter pylori infection status in patients with gastritis and gastric ulcer. Asian Pac J Cancer Prev. 2019;20(11):3497-3503.

19. Kwon DH, Dore MP, Kim JJ, Kato M, Lee M, Wu JY, Graham DY. High-level beta-lactam resistance associated with acquired multidrug resistance in Helicobacter pylori. Antimicrob Agents Chemother. 2003;47(7):2169-78.

20. Liyen Cartelle A, Uy PP, Koehler TE, Yap JEL. Persistent Helicobacter pylori infection: An insight to the limitations of current clinical practice. Cureus. 2020;12(12):e12309.

21. Gisbert JP. Empirical or susceptibility-guided treatment for Helicobacter pylori infection? A comprehensive review. Therap Adv Gastroenterol. 2020;13:1756284820968736.

22. Okamoto T, Yoshiyama H, Nakazawa T, Park ID, Chang MW, Yanai H, Okita K, Shirai M. A change in PBP1 is involved in amoxicillin resistance of clinical isolates of Helicobacter pylori. J Antimicrob 
Chemother. 2002;50(6):849-56.

23. Saniee P, Hosseini F, Kadkhodaei S, Siavoshi F, Khalili-Samani S. Helicobacter pylori multidrug resistance due to misuse of antibiotics in Iran. Arch Iran Med. 2018;21(7):283-288.

24. Diab M, El-Shenawy A, El-Ghannam M, Salem D, Abdelnasser M, Shaheen M, Abdel-Hady M, ElSherbini E, Saber M. Detection of antimicrobial resistance genes of Helicobacter pylori strains to clarithromycin, metronidazole, amoxicillin and tetracycline among Egyptian patients. The Egyptian Journal of Medical Human Genetics. 2018.

25. Ortiz V, Estevez-Ordonez D, Montalvan-Sanchez E, Urrutia-Argueta S, Israel D, Krishna US, RomeroGallo J, Wilson KT, Peek RM, Dominguez R, Morgan DR. Helicobacter pylori antimicrobial resistance and antibiotic consumption in the low-resource Central America setting. Helicobacter. 2019;24(4):e12595.

26. Azzaya D, Gantuya B, Oyuntsetseg K, Davaadorj D, Matsumoto T, Akada J, Yamaoka Y. High antibiotic resistance of Helicobacter pylori and its associated novel gene mutations among the Mongolian population. Microorganisms. 2020;8(7).

27. Aumpan N, Vilaichone RK, Gamnarai P, Sanglutong L, Ratanachu-Ek T, Mahachai V, Yamaoka Y. Prevalence and antibiotic resistance patterns of Helicobacter pylori infection in Koh Kong, Cambodia. Asian Pac J Cancer Prev. 2020;21(5):1409-1413.

28. Camorlinga-Ponce M, Gomez-Delgado A, Aguilar-Zamora E, Torres RC, Giono-Cerezo S, Escobar-Ogaz A, Torres J. Phenotypic and genotypic antibiotic resistance patterns in Helicobacter pylori strains from ethnically diverse population in Mexico. Front Cell Infect Microbiol. 2020;10:539115.

29. Li J, Deng J, Wang Z, Li H, Wan C. Antibiotic resistance of Helicobacter pylori strains isolated from pediatric patients in Southwest China. Front Microbiol. 2020;11:621791.

30. Binh TT, Shiota S, Nguyen LT, Ho DD, Hoang HH, Ta L, Trinh DT, Fujioka T, Yamaoka Y. The incidence of primary antibiotic resistance of Helicobacter pylori in Vietnam. J Clin Gastroenterol. $2013 ; 47(3): 233-8$.

31. Nguyen NV, Do NTT, Nguyen CTK, Tran TK, Ho PD, Nguyen HH, Vu HTL, Wertheim HFL, van Doorn HR, Lewycka S. Community-level consumption of antibiotics according to the AWaRe (Access, Watch, Reserve) classification in rural Vietnam. JAC Antimicrob Resist. 2020;2(3):dlaa048.

32. Seo JW, Park JY, Shin TS, Kim JG. The analysis of virulence factors and antibiotic resistance between Helicobacter pylori strains isolated from gastric antrum and body. BMC Gastroenterol. 2019;19(1):140.

33. Godoy AP, Ribeiro ML, Benvengo YH, Vitiello L, Miranda Mde C, Mendonca S, Pedrazzoli J, Jr. Analysis of antimicrobial susceptibility and virulence factors in Helicobacter pylori clinical isolates. BMC Gastroenterol. 2003;3:20.

34. Nguyen TL, Uchida T, Tsukamoto Y, Trinh DT, Ta L, Mai BH, Le SH, Thai KD, Ho DD, Hoang HH, Matsuhisa T, Okimoto T, Kodama M, Murakami K, Fujioka T, Yamaoka Y, Moriyama M. Helicobacter pylori infection and gastroduodenal diseases in Vietnam: a cross-sectional, hospital-based study. BMC Gastroenterol. 2010;10:114. 
35. Trang TT, Shiota S, Matsuda M, Binh TT, Suzuki R, Vilaichone RK, Mahachai V, Tshering L, Dung HD, Uchida T, Matsunari O, Myint T, Khien VV, Yamaoka Y. The prevalence of Helicobacter pylori virulence factors in Bhutan, Vietnam, and Myanmar is related to gastric cancer incidence. Biomed Res Int. 2015;2015:830813.

36. Milad SSA, Korosh A, Reza A, Ghorbanali R, Yousef M, Rana F, Mojtaba S, Fatemeh A. Frequency of virulence-associated genotypes of Helicobacter pylori and their correlation with clinical outcome and histological parameters in infected patients. CelPress. 2021;Heliyon 7:e07610.

37. Loivukene K, Kolk H, Maaroos HI, Kasenomm P, Ustav M, Mikelsaar M. Metronidazole and clarithromycin susceptibility and the subtypes of vacA of Helicobacter pylori isolates in Estonia. Scand J Infect Dis. 2000;32(1):59-62.

38. Feliciano O, Gutierrez O, Valdes L, Fragoso T, Calderin AM, Valdes AE, Llanes R. Prevalence of Helicobacter pylori vacA, cagA, and iceA genotypes in Cuban patients with upper gastrointestinal diseases. Biomed Res Int. 2015;2015:753710.

39. Akeel M, Shehata A, Elhafey A, Elmakki E, Aboshouk T, Ageely H, Mahfouz M. Helicobacter pylori $v a c A, c a g A$ and $i c e A$ genotypes in dyspeptic patients from southwestern region, Saudi Arabia: distribution and association with clinical outcomes and histopathological changes. BMC Gastroenterol. 2019;19(1):16.

40. Qureshi NN, Gallaher B, Schiller NL. Evolution of amoxicillin resistance of Helicobacter pylori in vitro: characterization of resistance mechanisms. Microb Drug Resist. 2014;20(6):509-16.

\section{Figures}




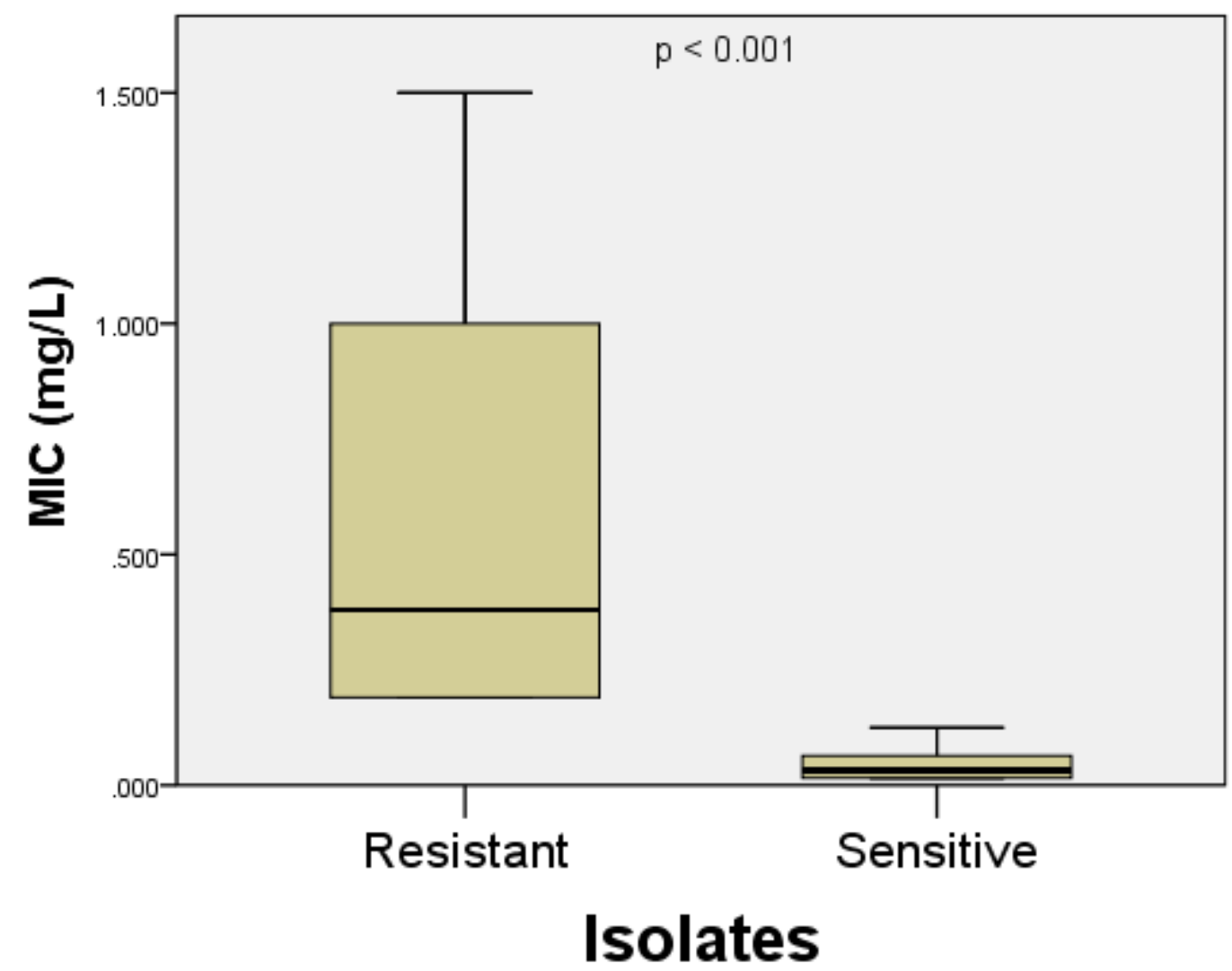

Figure 1

MIC range of isolates sensitive and resistant to amoxicillin

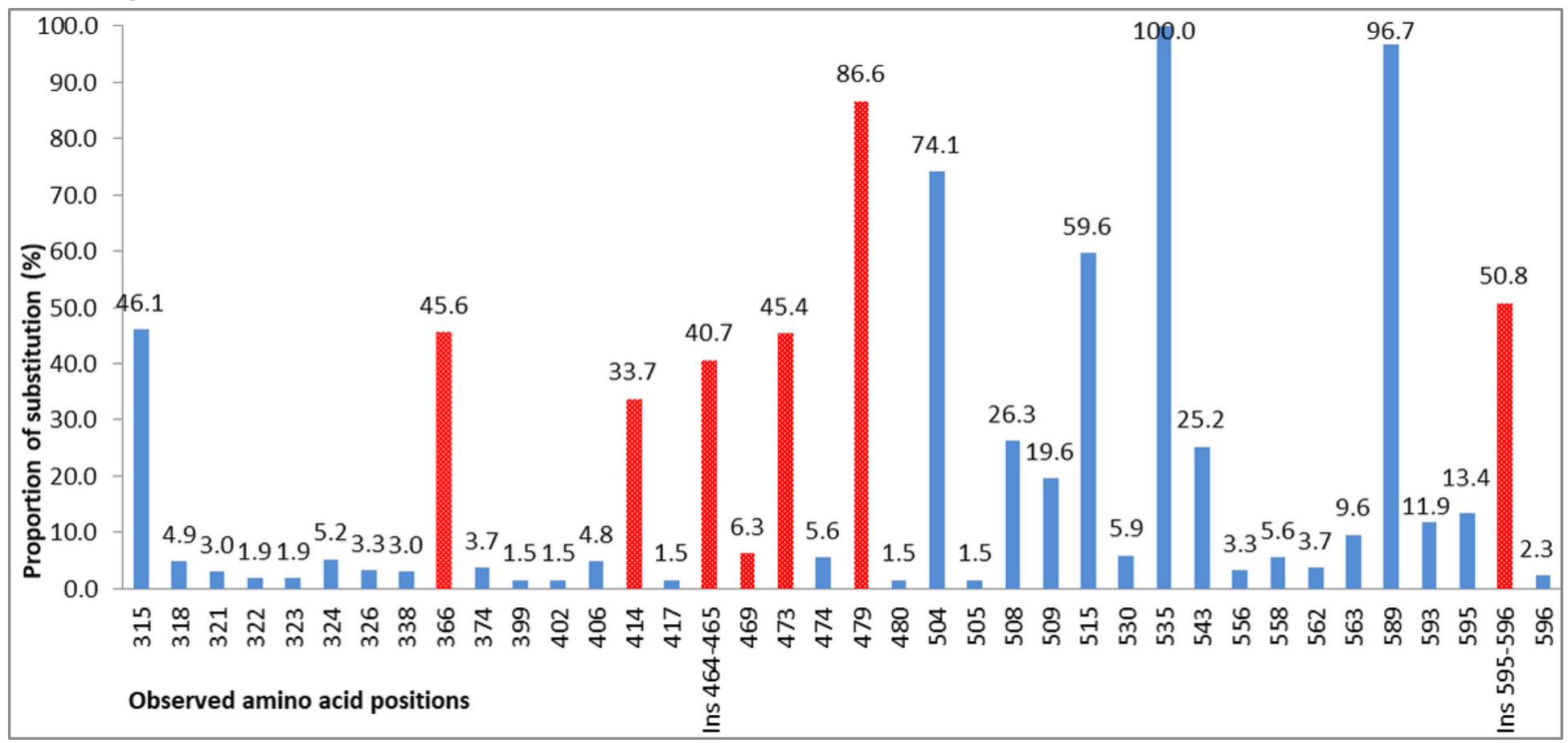

Figure 2 
Amino acid substitution proportion of deduced PBP-1A discovered in the population compared to the AmxS H. pylori strain 26695. Red represents amino acid substitution differences with statistical significance from AmxS and AmxR samples by the E-test. A proportion lower than $1 \%$ was not included in the picture.



Figure 3 
Phylogenetic tree of 85 sequences of the pbp1A gene obtained in this study. Scale bars indicate the numbers of nucleotide substitutions per site. Red nodes/tips represent pbp1A nucleotide sequences from the clinical specimens in which $\mathrm{H}$. pylori isolates showed resistance to amoxicillin. 